\title{
A Linguistic and Theological Assessment of the Gap Theory with Particular Reference to Genesis 1:1-2b
}

\begin{abstract}
Over the years, Christian scholars have made various attempts to explain the origin of the universe based on the Genesis account of creation. Three key evangelical interpretations of Genesis 1:1-3, namely, the restitution theory, the gap theory, and the precreation chaos theory, have emerged from the debate. Of particular importance to the present study is the gap theory which attempts to reconcile the Genesis account of creation with the geological claim that the earth is billions of years old. Advocates of the gap theory argue that God initially created a perfect universe in Genesis 1:1 which became imperfect in Genesis $1: 2$ as a result of a cataclysm. Though appealing, the linguistic and theological basis for this popular theory has been questioned by many biblical scholars. The purpose of this paper is to investigate the validity of the gap theory through a linguistic and theological examination of Genesis $1: 1-2 b$. At the end the study found that the gap theory does not rest on solid exegetical, theological and linguistic grounds.
\end{abstract}

Keywords: Creation, Gap Theory, Geological Ages, Linguistics.

\author{
ISAAC BOAHENG ${ }^{1}$ \\ ${ }^{1}$ Isaac Boaheng holds a Master of Divinity \\ degree from the Trinity Theological \\ Seminary. He is a Translator with the \\ Bible Society of Ghana and a Minister \\ of the Methodist Church Ghana serving \\ the Nkwabeng Circuit of the Sunyani \\ diocese. Credit is given to Dr. Samy Tioyé \\ (United Bible Societies' Global Translation \\ Advisor) under whose tutelage at St. Paul's \\ University, Limuru, Kenya, I had the \\ motivation to write this paper. \\ Email: revisaacboaheng@gmail.com
}

\author{
Manuscript \\ Received 19th February 2020, \\ Accepted 8th April 2020, \\ Published online 1st May 2020.
}

\section{INTRODUCTION}

\section{A brief historical overview of the Gap Theory}

The gap theory, also known as the "ruin-and-reconstruction theory" or the "pre-Adamic cataclysm theory", contends that God made an earlier creation which He later judged and destroyed due to Satan's rebellion against Him. ${ }^{2}$ The result of the destruction of the earth created in Genesis 1:1 is what one reads in 1:2: "Now the earth was formless and empty." In other words, God recreated the earth after the first earth was destroyed (see Gen. 1:3ff). There is therefore a "gap" between Genesis 1:1 and 1:2, into which go all the geological ages:

[Genesis 1:1] In the beginning God created the heaven and the earth.

[huge time gap]

[Genesis 1:2] And the earth was ["became"] without form, and void; ...

Scholars trace the origin of modern gap theory to Thomas Chalmers (1780-1847), a notable Scottish theologian and the first moderator of the Free Church of Scotland. ${ }^{3}$ Chalmers had great interest in geology and he studied the works of many geologists including James Hutton. ${ }^{4}$ His studies led to his acceptance of the view that the earth is billions of years old. Chalmers found it difficult to accept this geological claim along with biblical account of creation in Genesis. To be precise, Chalmers struggled with how he could harmonize the apparent short scale of world history found in Genesis

\footnotetext{
Henry M. Morris, The Genesis Record: A Scientific and Devotional Commentary on the book of Beginnings (Grand Rapids, MI: Baker Book House, 1998$), 46$. W.W. Fields, Unformed and Unfilled (Collinsville, IL: Burgeners Enterprises, 1976), 40. See also Chuck Missler, Supplemental Notes: The Book of Ezekiel (Coeur d'Alene: Koinonia House, 2008), 203. PDF see also Morris, The Genesis Record, 46.

4 Fields, Unformed and Unfilled, $40 \mathrm{ff}$.
} 
with the geological idea that the world is exceedingly old (about 4.5 billion years). His attempt to handle the issue led to his proposal of a huge time gap between the first two verses of Genesis 1. Though he did not write much on the subject, Chalmers' teachings influenced many theologians who came after him.

In the 21st century, Scofield popularized the gap theory through the publication of his Study Bible. In his notes on Genesis 1:1, Scofield states that the "first creative act refers to the dateless past and gives scope for all the geologic ages." Referring to the third day of the "new creation" when God commanded earth to "bring forth" vegetation, Scofield asserts that seeds probably survived the catastrophic judgment of Genesis 1:2 and could grow again in the newly reconstituted earth.

The most notably influential nineteenth century writer to popularize the gap theory was G. H. Pember, who wrote "It is clear that the second verse of Genesis describes the earth as a ruin; but there is no hint of the time which elapsed between creation and this ruin... There is room for any length of time between the first and second verses of the Bible." $\mathrm{He}$ added, "since we have no inspired account of the geologic formations, we are at liberty to believe that they were developed just in the order in which we find them. The whole process took place in pre-Adamite times, in

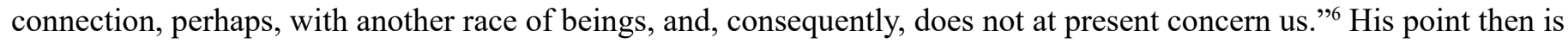
that since there is evidence of fossil remains of creatures who lived before Adam and these animals experienced disease, death and mutual destruction, they must have been in a different world. ${ }^{7}$

Harry Rimmer also contributed to the development of the gap theory through his 1941 publication Modern Science and the Genesis Record. In this work, Rimmer argued that the first verse of Genesis refers to the original creation of the earth. ${ }^{8} \mathrm{He}$ asserted further, "Only God knows how many ages rolled by before the ruin wrought by Lucifer fell upon the earth, but it may have been an incalculable span of time. Nor can any students say how long the period of chaos lasted; there is not even a hint given. But let us clearly recognize in these studies that Moses, in the record of the first week of creation, is telling the story of God's reconstruction; rather than the story of an original creation." Rimmer is saying that what God did in Genesis 1:3ff is a re-creation rather than original creation.

The most outstanding academic defense for the gap theory in the 20th-century was given by Arthur C. Custance in his 1970 work Without Form and Void. Arthur Custance also assumes chaos, saying, "Essentially, there are two possible interpretations of Gen 1:2. Either it is a chaos which marks the first stage of God's creative activity, or it is a chaos which resulted from some catastrophic event marring what had formerly been an orderly and beautiful world." 10 Custance traces this theory to some early Jewish scholars, some of the church fathers, and even to some ancient Sumerian and Babylonian documents. ${ }^{11} \mathrm{He}$ also argues that, "We are told that in the beginning God created the heavens and the earth; but the Scriptures never affirm that He did this in the six days." ${ }^{12}$ In a section subtitled "Order Out of Chaos," Merrill Unger states,

If Genesis 1:1 refers to the original creation of the universe out of nothing, Genesis 1:2 must either be construed to be the original chaotic state in which the earth was created or to be the result of a subsequent judgment (the gap theory). But the first interpretation is contradicted by both Scripture and theology. Why should a perfect Creator create an original imperfect and chaotic earth? - the fact of which is expressly denied by revealed truth recorded in Isaiah 45:18 and completely at variance with the ecstatically joyous dedication of the primeval earth when it came forth perfect from the Creator's hand, as described by Job (Job 38:4-7). ${ }^{13}$

Unger contends that the initial creation from God could not have been chaos. Therefore, the only option is that the earth must have "become" chaos in a time gap at Genesis 1:2.

\section{Major arguments for the Gap theory}

Proponents of the gap theory appeal to linguistics for support to their claims. Two major linguistic arguments are made to support this theory. First of all, it is argued that the word $b \bar{a} r \bar{a}$ ' in Genesis $1: 1$ is a strong verb which means "to create" (from nothing), while 'āsāh (in Gen. 1:7, 16, 25, 26, 31;2:2) is a weaker verb which means "to restore" or "to remake."14 Gap theorists argue for two creation accounts in Genesis 1, namely, the bāra stage of Creation and the 'āsāh stage (the "six days"), which are separated by centuries or even billions of years. ${ }^{15}$ Strictly speaking, $b \bar{a} r \bar{a}$ refers to the original

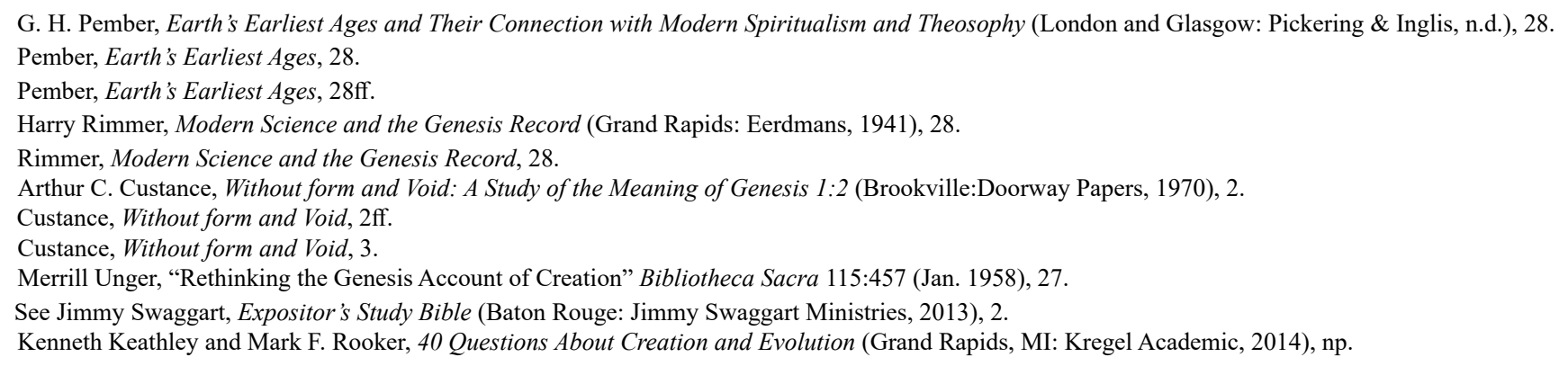


creation while $\bar{a} s \bar{a} h$ refers not to creation but to the assigning of a new role to something that already exists. ${ }^{16}$ In support of this view, Jimmy Swaggart asserts (concerning Genesis 1:2) that, "God did not originally create the earth without form and void; it became this way after a cataclysmic happening; this happening was the revolt of Lucifer against God, which took place sometime in the dateless past." ${ }^{\prime 17}$ Therefore, what we read of in Genesis 1:3-2:3 is really a second attempt by God to re-create the universe.

While the first argument relates to semantics, the second relates to grammar. It is argued that the Hebrew waw is disjunctive, implying an interruption in the narration from what is reported in Genesis 1:1. Related to this argument is the claim that the verb "was" (Hb: hayethah) should be translated "became" or "had become"18 to suggest a change of state from the original perfect creation to the chaotic condition inferred from verse 2. ${ }^{19}$ Missler, like Dake, argues strongly that the verb hayethah must be considered in the pluperfect form to mean "had become" in the same way Lot's wife "became" a pillar of salt (cf. Gen 19:26). ${ }^{20}$

It is further argued that the expression $t \bar{o} h \bar{u} v \bar{a}-b \bar{o} h \bar{u}$, which is traditionally translated "without form and void" (Gen 1:2) signifies a degeneration of the original creation, and thus what follows is a re-creation. For gap theorists, the expression $t \bar{o} h \bar{u} v \bar{a}-b \bar{c} h \bar{u}$ is used in Isaiah 34:11 and Jeremiah 4:23 in the context of judgment oracles and therefore, the Genesis usage should be understood as in the context of God's judgement as well. ${ }^{21}$ In other words, the expression "without form and void" in Genesis 1:2, Jeremiah 4:23-27; Isaiah 24:1; 45:18 clearly signifies that the earth had experienced a cataclysmic change as the result of divine judgment. ${ }^{22}$ It is also argued that "darkness" represents evil in Scripture, and therefore the presence of darkness in Genesis 1:2 signifies a falling away from the perfection of Genesis 1:1. Chuck Missler, for instance, contends that "darkness" in Genesis 1:2 is "felt" as in Exodus 10:21 and, thus, unnatural, which signifies the presence of Satan in that formless and void earth. ${ }^{23}$

The gap theory also incorporates the idea of mankind populating the earth before Adam (referred to as a preadamic race) who existed until Satan rebelled against God. Therefore, Adam and Eve were supposed "to refill" the earth rather than "to fill" it (Gen 1:28). Swaggart argues that the word male, translated "fill" in Genesis 1:28, must point to recreation: "the word 'replenish' carries the idea of a former creation on the Earth before Adam and Eve" because "according to Isaiah 14 and Ezekiel 28, Lucifer ruled this world for an undetermined period of time and did so in Righteousness and Holiness as a beautiful Angel created by God; if, in fact, he did rule the world at that time; it would stand to reason that there had to be some type of creation on the earth for him to rule; the word "replenish" refers to that creation." ${ }^{24}$ Having considered the arguments put forward by gap theorists, the study now continues to conduct a linguistic and theological analyses of the text to ascertain the validity or otherwise of the claims of gap theorists.

\section{Linguistic Analysis of Genesis 1:1-2}

Before looking at the text from a linguistics viewpoint, it is important to give a brief outline of the subject of Linguistics. Linguistics refers to the scientific study of language and its structure. According to Kofi Agyekum language refers to "a collection of symbols, letters or words with arbitrary meanings that are governed by rules and conventions that help people to communicate effectively." ${ }^{25}$ Agyekum quotes Sapir as defining language as "a system of phonetic symbols for the expression of communicable thought and feeling." 26

There are various branches of Linguistics. ${ }^{27}$ First, we have phonetic or phonological level, which basically deals with sound systems, their combination and contrast. Other areas of interest under this branch include fixed number of phonetic sounds, sound distribution (the way phonetic sound group themselves) and prosodic features such as pitch, intonation, stress, tone, loudness, duration and rhythm. To study the phonetics of a language one must practice producing (sometimes exotic) sounds, and then make a critical analysis of the sound made to determine which sound it is. Another branch of Linguistics is morphology which focuses on the formation of words from smaller portions of meaningful units called morphemes. The morphemes contained in the word untied are /un/ referring to the process of reversing an action; /tie/ referring to the fastening together of two ends of a piece of string to stay and /d/ which shows that the action was done in the past. Morphemes in a language can be determined by comparing word forms with one another and

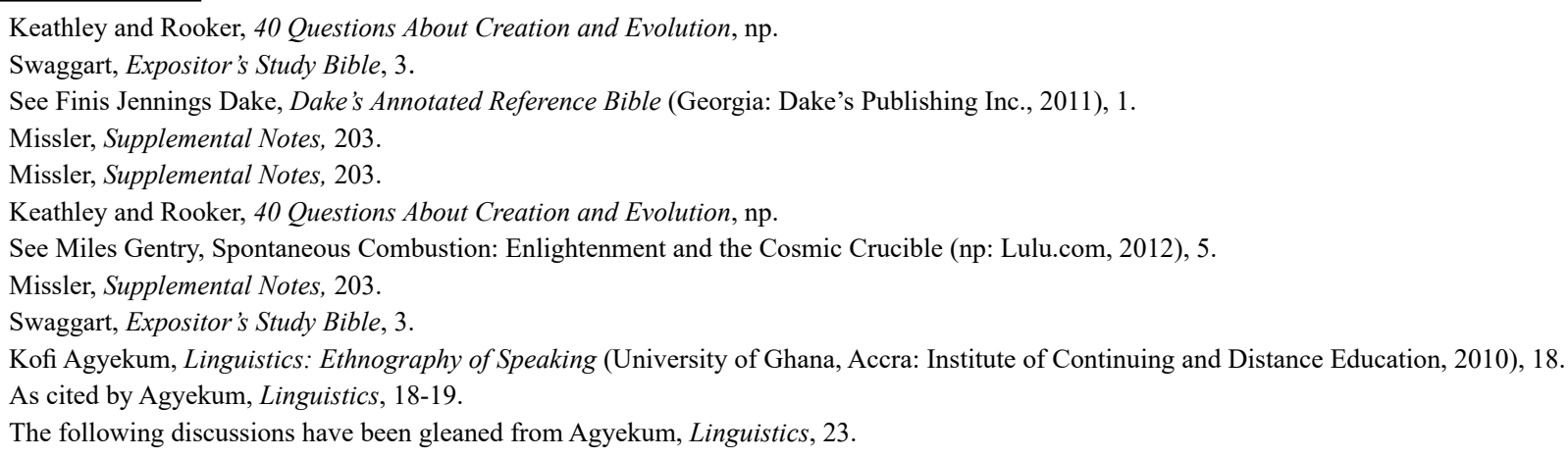


noting the repeated pieces that compose them. Every language has peculiar ways by which words are formed. Words are the basic grammatical meaningful units. Syntax is another branch of linguistics. It deals with the "arrangement of words and phrases to create well-formed sentences in a language." ${ }^{28}$ It focuses on the rules governing how words are ordered to form phrases, clauses and sentences. The next branch of Linguistics is semantics which focuses on meaning, changes in meaning, and the principles that govern the relationship between sentences or words and their meanings. In other words, semantics has to do with establishing the relation between words, phrases and other parts of language and how these words and phrases connect to the world. It also deals with the study of the relationships between signs and symbols and what they represent. Finally, we have pragmatics, which is the branch of linguistics which focuses on the explanation about meaning of an utterance in each context or the study of the meaning delivered by the speaker (writer) and interpreted by the listener (reader). Pragmatic includes such matters as deixis, the taking of turns in conversation, text organization, presupposition, explicature and implicature. With this brief background the study now proceeds to analyze the text linguistically.

\section{Verse 1}

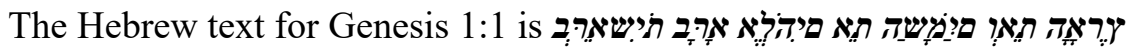
Transliterated into English gives: Berēshît bārā Elohim êt hashāmayim w'êté hā'ārets

Various suggestions can be made about the role of Genesis 1:1 in the creation account. The NRSV reflects the variety of linguistic interpretations that are available and offers three options: (1) in the main text, In the beginning when God created the heavens and the earth; and in footnotes (2) When God began to create... and (3) In the beginning God created .... The first option assumes that the preposition be is used in a temporal circumstantial sense, and hence the clause is to be considered as a hypotactic temporal one. ${ }^{29}$

\section{Berēshît}

Literally, in a first, perhaps meaning at commencement, or initially, the term berēshît refers to the absolute beginning of created things. At least two reasons can be gathered in support of the idea that beresshît underscores the absolute beginning of created things. ${ }^{30}$ Firstly, the Septuagint translators rendered it en arche, an expression which also occurs at the beginning of John's gospel (1:1) in reference to the time when creation activity began. Secondly, taking this expression as the absolute beginning of creation makes a simple and natural progression of thought. However, berēshît seems to mean "in the beginning of" rather than "in the beginning." ${ }^{11}$ If this is true then verse 1 should be taken with verse 3 so that we have the rendering "In the beginning of God's creating the heaven and the earth, God said let there be..." 32 In the present context berēshît refers to "the beginning" of time itself, not sometime within eternity. Before the beginning, God existed, and so the hymn writer could say, "Before the mountains were brought forth, or ever you had formed the earth and the world, from everlasting to everlasting you are God" (Psalm 90:2).

\section{$\boldsymbol{B} \overline{\boldsymbol{a}} \boldsymbol{r} \bar{a}$}

The word $b \bar{a} r \bar{a}$ (qatal 3ms), translated "created" is always only used in relation to God's works. ${ }^{33}$ Apart from this text, the Hebrew verb $b \bar{a} r \bar{a}$ is used in 1:21, 27(3x); 2:3; 5:1-2 (3x); 6:7. Three key observations about $b \bar{a} r \bar{a}$ can be made. Firstly, God is always the subject of bara. Therefore, the creation activity is exclusively divine. The second observation is that "whenever the verb is used, its direct object is always the product created, never the materials used as the means in creation." ${ }^{34}$ According to Gerhard von Rad, "It is correct to say that the verb bara, 'create,' contains the idea both of complete effortlessness and creatio ex nihilo, since it is never connected with any statement of the material." 35 The word $b \bar{a} r \bar{a}$ does not of itself and absolutely exclude the use of existing material (see Isaiah 65:18b, 27). However, no existing material is implied, if no such material is mentioned as to be worked over. Therefore, though the idea of creatio ex nihilo (creation out of nothing) is not stated explicitly, it can be implied from the word bara. The universe had no prior existence to this primeval creative activity of God. This means that the universe is not eternal as God is. The universe came into existence only when God commanded it to begin to exist. God is not only eternal; He is also omnipotent for without having all-powers God could not have commanded the universe to come into existence. The idea of creatio ex

\footnotetext{
William A. Kretzschmar, Jr, The Emergence and Development of English: An Introduction (Cambridge: Cambridge University Press, 2018 ), 226.

Barry Bandstra, Genesis 1-11: Baylor Handbook on the Hebrew Bible edited by W. Dennis Tucker Jr. (Texas: Baylor University Press, 2008$), 43$.

See H C Leupold, Exposition on Genesis (Grand Rapids, MI: Baker Book House, 1942), 39.

Cuthbert A. Simpson, "Genesis” in George Arthur Buttrick (ed.), The Interpreter's Bible Vol. 1 (New York: Abingdon Press, 1956$), 466$.

Simpson, "Genesis", 466

Claus Westermann, Genesis translated by David E. Green (London: T8.T Clark International, 2004), 8.

Victor P. Hamilton, Handbook on the Pentateuch: Genesis, Exodus, Leviticus, Numbers, Deuteronomy (Grand Rapids, MI: Baker Book House, 1982), np.

Gerhard von Rad as cited by Paul Copan and William Lane Craig, Creation Out of Nothing: A Biblical, Philosophical, and Scientific Exploration

(Leicester: Inter-Varsity Press, 2004), 25.
} 
nihilo is thought in passages such as Romans 4:17; Hebrews 11:3; cf. Psalm 33:6, 8; Amos 4:13. Thirdly, bārā is not in a construct or bound relationship with rēsît so that the phrase will be translated in the beginning of God's creating. According to Bandstra, if $b \bar{a} r \bar{a}$ were in construct form both components of the phrase would have been nominal forms,

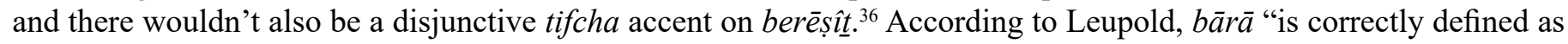
expressing the origination of something great, new and 'epoch-making,' as only God can do it, whether it be in the realm of the physical or of the spiritual." ${ }^{37}$

Contrary to the contention that $\bar{a} s \bar{a} h$ usually means "make" and not "create" the present writer finds evidence from Scripture to show that $\bar{a} s \bar{a} h$ can also mean create. First, we acknowledge that the root 'āsāh is used numerous times in the creation account in the sense of "to do" or "to make" (Gen 1:7, 16, 25, 26, 31: 2:2-3). However, we find throughout the creation account that $b \bar{a} r \bar{a}$ and $\bar{a} s \bar{a} h$ are used virtually synonymously. The verb $\bar{a} s \bar{a} h$ appears to have the same meaning as $b \bar{a} r \bar{a}$ in Genesis $1: 7 ; 1: 6 ; 1: 25$. Both verbs are used in conjunction with the creation of humankind (Gen 1:26-27). The word $\bar{a} s \bar{a} h$ is also used in connection with the creation of the heaven and earth (Exod 20:11; Neh 9:6). Though Nehemiah (9:6) alludes to the original creation of the universe out of nothing, he still uses the word $\bar{a} s \bar{a} h$. In Genesis 1:31 it is used at the conclusion of the six days of creation in reference to all that God had created. Bāra and $\bar{a} s \bar{a} h$, appear to be interchangeable and parallel in Genesis 2:4; Exodus 34:10; Isaiah 41:20, 43:7 and Psalm 148:1-5.

\section{Elohim}

The first noun in the Hebrew Bible is Elohim, the name for God which emphasizes His majesty and omnipotence. It is no accident that God is the subject of the first sentence of Genesis because His name here is frequent in the whole chapter, occurring some thirty-five times in all. The writer used this repetitious use of Elohim to underscore the centrality of God in the creation story. The im ending of this word (Elohim)makes it a plural noun (actually the masculine plural of

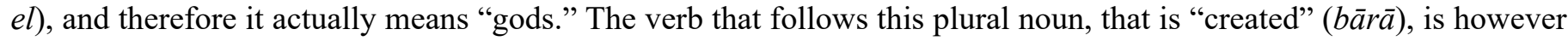
in the singular, so that we have God (plural) created (singular). ${ }^{38}$ In some contexts, Elohim refers to idol deities (cf. Exod 23:24; Deut 7:14; Josh 24:10; 1 Kings 9:9; Ezra 1:7; Psalms 95:3; 96:5; Isa 42:17). However, it is used here in the singular to underline God's might, and probably, His uni-plurality. ${ }^{39}$

\section{Hashämayim we'et ha'arets}

The object of God's creation was "the heavens and the earth," that is, the universe. The author probably preferred the expression "heavens and earth" because of the lack of a Hebrew word for universe. What Hebrew speakers can talk about is "the all", meaning everything (cf. Jer 10:16; Isa 44:24; Ps 103:19; 119:91; Eccles 11:5). This clause consists of two nominal groups conjoined with the conjunction we. Like Elohim, the word shamayim is a masculine plural noun (plural of intensity) and can be translated either as "heaven" or "heavens", based on the context within which it is used and on whether it is used in with a singular or plural verb. Shämayim derives from sham ("there") and mayim ("waters") $)^{40}$ and it is used in the sense of "upper regions," "sky" or "firmament" signifying the heavenly spheres which rise one above the other (cf. Genesis 1:8ff, 15ff; 2:1,4; Exodus 20:11; Deuteronomy 4:32), as the realm of stars and as the dwelling place of God (Genesis 24:3; Ezra 1:2; Ecclesiastes 5:2) ${ }^{41}$ It looks formally like a dual because it ends in yim, but the form is a plural of shama with unaccented yim-ending. By attaching a definite article to the noun (to make it ha shämayim), the author presumes that it has already been defined or is presumably known in given a common world view. In other words, the author makes use of information that he shared with his audience. Hā $\bar{a}$ rets may refer to "earth", "country" (in the sense of one's homeland cf. Genesis 20:1; 24:62; 30:25; 32:9; Ezekiel 20:42; 34:15 or "ground" (cf. Gen 37:10; Exod 10:3ff; Num 11:31).

\section{Verse 2}

The Hebrew text of verse 2 reads:

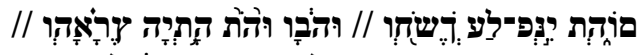

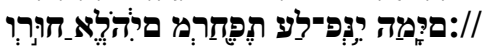

The transliterated text for the first two clauses is: ${ }^{42}$

\section{Wehā'āets hayetah tōhô wā $\underline{b} \bar{o} h \hat{u}$ \\ Wechoshek'al penê tehôm}

This verse consists of three independent clauses (divided by two slashes [//]) each introduced with the clause conjunction

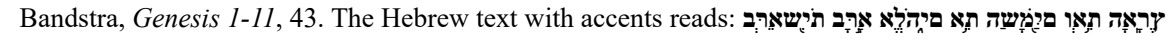

See Leupold, Exposition on Genesis, 40.

Bandstra, Genesis 1-11, 43.

Morris, The Genesis Record, 39.

Morris, The Genesis Record, 40.

Stephen D. Renn (ed.), Expository Dictionary of Bible Words (Peabody, Massachusetts: Hendricks Publishers Marketing, Inc., 2005$), 479$.

The study concentrates on the first two clauses (that is verse $2 \mathrm{a}-\mathrm{b}$ ).
} 
we. The first is an expansion of the last clause of verse 1, the second adds specification to and the third describes $h \bar{a}$ 'arets in the first verse. That is to say that "each clause makes a statement about a preexisting component in order to characterize the state of the earth before deity's first act of creation." ${ }^{43}$ This declarative clause containing an attributive relation between the carrier (that is the earth) and the attributes (an emptiness and a void).

\section{Hayetah}

The writer expands on his initial statement, making the earth his vantage point (cf. Psalm 115:16). In Genesis 1:2, the waw conjunction (translated "and") is used disjunctively (that is, it is attached a noun) to signify a shift in the narrative. ${ }^{44}$ Syntactically, the first item in verse 2 is not the verb, but the term we-ha' 'arets, in which the initial we- is translated "and" in many Bibles (including KJV, NRSV). The particle we is "waw circumstantial", as opposed to "waw consecutive", the form opening verse $3 .{ }^{45} \mathrm{~A}$ waw circumstantial is formed by attaching the waw to a noun (Hebrew form we + noun) while a waw consecutive is formed when a waw is joined to a verb. ${ }^{46}$ The waw consecutive is translated "and" (as in And said God ... verse 3) but the waw circumstantial is to be translated as "now" (as in Now the earth was, ... verse 2). Thus, the first clause in verse 2 is circumstantial, while the first clause in verse 3 is consecutive. The event in verse 3 happened after the situation in verse 2, whereas the situation in verse 2 represents circumstances when creation was at its beginning. Therefore, "Genesis 1:2 explains more clearly the condition or the circumstances attending God's creative act. Genesis 1:2 is thus a description of the earth as originally created." ${ }^{17}$ For Fields, "The use of the waw disjunctive in Genesis 1:2, as well as the fact that the passage consists of three circumstantial clauses, indicates that the clauses of which it composed are a description of the action of the main verb (namely, the action of creating the heaven and the earth in Gen 1:1), not a chronologically sequential development after 1:1. Verse 2 sets the scene, making the earth our vantage point; whatever the total pattern, this is our concern." 48

It is a fact that grammar allows the pluperfect sense "had become" and usage shows that the verb "to be" can mean "to become" (as in Genesis 19:26; Judges 11:39; 2 Kings 17:3). However, as Charles C. Ryrie notes, in "the present case "the verb normally serves as a linking verb ('to be' not 'to become'), as in Genesis 1:25 and 3:1 where it could not be understood as 'to become." "49 Ryrie argues further that "the disjunctive use of the waw seems required because the author apparently is calling the reader's attention to something about the earth-'now as to the earth it was ...." ${ }^{50}$ More so, while contextual situation may require the translation of hayethah as "become" such a rendition occurs only 22 of its 1, 522 appearances in the Pentateuch.

Word order is very important in the current study. As noted earlier, consequent events and single events have the verb preceding the noun while circumstantial assertions have the noun preceding the verb, in which case the noun is the centre of attention. The importance of word order in English, for instance can be deduced from the following three sentences: (1) Only Benedict could carry the bag; (2) Benedict only could carry the bag; (3) Benedict could only carry the bag. The first statement means no one could carry the bag except Benedict; the second means Benedict (without the help of anyone) could carry the bag; the third means all that Benedict could do was to carry the bag. Just as a change in word order leads to a change in meaning in English (as evident in the sentence) so it is in Hebrew.

Most scholars agree that "the Hebrew verb [hayethah] translated was refers to the time when God began his work of creation. Was does not mean that the earth remained in this shapeless state for a long time; nor does it mean that it became such after being something else earlier." ${ }^{1}$ The verb hayethah of Genesis 1:2 is translated "was" in all the standard translations because that is its meaning. The following contextual analysis pushes the argument further. If God first forms the earth (v. 1) and then later creates light (v. 3), then logically the earth described in verse 2 must have darkness over it (because light had not been created). The text makes it clear that creation took place progressively rather than instantaneously. Further, the darkness, which according to gap theorists suggests judgment, was present during all the six days of creation to mark the end or beginning of a day (see v. $5 ; 8 ; 13 ; 18-19$ ) without suggesting any evil present.

\footnotetext{
Bandstra, Genesis 1-11, 44.

Keathley and Rooker, 40 Questions About Creation and Evolution, np.

Keathley and Rooker, 40 Questions About Creation and Evolution, np.

For more on this, consult Isaac Boaheng, Basic Biblical Hebrew (Sunyani: Jonnette Secretarait, 2020), 84-85.

Keathley and Rooker, 40 Questions About Creation and Evolution, np.

Fields, Unformed and Unfilled, 86 (emphasis original).

Charles C. Ryrie, Systematic Theology (Chicago, IL: Moody Publishers, 1999), 210.

Ryrie, Systematic Theology, 210.

William D. Reyburn and Euan McG Fry, A Handbook on Genesis (New York: United Bible Society, 1997), 30. (emphasis original)
} 
An exact usage of waw and hayethah is found in Jonah 3:3:

\begin{tabular}{|c|c|c|c|c|}
\hline Jonah $3: 3 b$ & we-Nineweh & hayethah & 'ir & gedolah \\
\hline & Now Nineveh & was & city & great \\
\hline Gene & $\begin{array}{l}\text { we-hā'-àrets } \\
\text { Now the earth }\end{array}$ & $\begin{array}{l}\text { hayethah } \\
\text { was }\end{array}$ & $\begin{array}{l}\text { tōh } \hat{u} \\
\text { formless }\end{array}$ & $\begin{array}{l}w \bar{a}-\underline{b} \bar{o} h \hat{u} \\
\text { and empty }\end{array}$ \\
\hline
\end{tabular}

We find the same form of the waw particle, the same word for "was" and the same initial word order. The full statement in Jonah 3:3 is "Jonah obeyed the word of the LORD and went to Nineveh. Now Nineveh was a very large city; it took three days to go through it." The context implies that the city of Nineweh was a great one before Jonah arrived. It was in that state before the visit of Jonah. The statement is not "Now Nineweh became a great city" as if it was not Jonah's visit that made Nineweh great. In the same vein, the earth was but did not become void and formless in Genesis 1:2.

\section{Tōhûu wābōhhu}

The words tōhh occurs together with wāb $\underline{x} \bar{o} \hat{u}$ in only three instances in the Old Testament (Gen 1:2; Isa 34:11; Jer 4:23). The word $w \bar{a} \underline{b} \bar{o} h \hat{u}$ occurs only in combination with tōhu, while tōhh may occur by itself, occurring alone about twenty times. It has been rendered a desert (Deut 32:10) or an abandoned city (Is 24:10), or vanities (1 Sam 12:21; Is 40:17) or space (Job 26:7). It can refer to a "wasteland," but does not refer to a "wasted land." The expression "without form and void" simply means that the earth was not, at that time, ready to be occupied; it was empty. Haines is therefore right to assert that "the natural sense of Genesis 1:2 is that [God] initially created the raw materials of the earth and then gradually perfected it." ${ }^{52}$ That means, God began with an imperfect state of the earth (Gen 1:2) and worked towards a perfect finished earth (Gen. 1:31). More so, God's perception of the whole creation as good (v. 31) will be meaningless if the world was full of the disastrous consequences of Satan's rebellion. Will God perceive a world full of demonic beings and evil as good? Certainly no. Again, the gap theory opposes the clear biblical teaching that everything was created in six days (cf. Gen 2:1; Exod 20:11). David T. Tsumura gives the following etymological analysis:

Hebrew tōh $\hat{u}$ is based on a Semitic root thw and means "desert." The term bōhî is also a Semitic term based on the root $b h w$, "to be empty." . . . The Hebrew term bōhû means (1) "desert," (2) "a desert-like place," i.e. "a desolate or

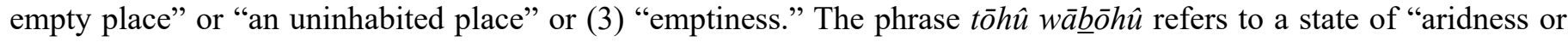
unproductiveness" (Jer 4:23) or "desolation" (Isa 34:11) and to a state of "unproductiveness and emptiness" in Genesis $1: 2.53$

Another passage that needs consideration for the use of tohh is Isaiah 45:18, which reads, "For thus says the Lord, who created the heavens (He is the God who formed the earth and made it, He established it and did not create it a waste place $[t \bar{o} h \hat{u}]$, but formed it to be inhabited)." (NRSV) On first appearance it seems that the text is suggesting that the state of unproductiveness presented in Genesis 1:2 was not part of God's initial plan, meaning it came as a result of judgement. However, a contextual analysis of the Isaiah 45:18 clarifies the use of tôh $\hat{u}$ in Genesis 1:2, as a contrast of läsebet "to inhabit", underscoring the fact that God created the earth to be inhabited, and not to leave it in a state of desolation $(t \bar{o} h \hat{u}) .{ }^{54}$ What the writer of Isaiah 45:18 is saying then is that, the initial desolate earth God created was not left in its state forever, but was formed to be suitable for habitation. Tsumura confirms this position in his assertion (about Isa 45:18) that, "tôh $\hat{u}$ here is contrasted with lāšebet in the parallelism and seems to refer rather to a place which has no habitation, like the term šemāmāh "desolation" (cf. Jer 4:27; Isa 24:12), hâarēb "waste, desolate" and 'ăzûbāh "deserted." There is nothing in this passage that would suggest a chaotic state of the earth "which is opposed to and precedes creation." Thus, the term tōĥे here too signifies "a desert-like place" and refers to "an uninhabited place." ...It should be noted that $l \bar{o}-t \bar{o} h \hat{u}$ here is a resultative object, referring to the purpose of God's creative action. In other words, this verse explains that God did not create the earth so that it may stay desert-like, but to be inhabited. So, this verse does not contradict Gen 1:2, where God created the earth to be productive and inhabited though it "was" still tōh $\hat{u}$ wäbōh $\hat{u}$ in the initial state." ${ }^{55}$

The text implies that creation was a progressive act, "from a state of 'nothingness' through a state of 'formlessness' and 'emptiness' to a condition where the 'formlessness' gave way to 'form' and the 'emptiness' surrendered to 'fullness." " 56 Thus, the writer's argument is that "God did originally create the world formless and void, but since this was not His ultimate wish for it, He proceeded to fill it with living things, including man." ${ }^{57}$ We can see the progression

\footnotetext{
Haines "Genesis", 24.

53 David T. Tsumura, “The Earth and the Waters in Genesis 1 and 2: A Linguistic Investigation,” JSOT Supplement Series 83 (Sheffield: JSOT

Press, 1989), 155-56.

54 Keathley and Rooker, 40 Questions About Creation and Evolution, np.

Tsumura, "The Earth and the Waters in Genesis 1 and 2", 33-34.

Lloyd J. Ogilvie (ed), The Preacher's Commentary (Nashville, TN: Thomas Nelson, Inc., 1987), np.

57 Ryrie, Systematic Theology, 210.
} 
in that, in the first three days of creation, the formlessness $(t \bar{o} h \hat{u})$ is given form while in the last three days, the emptiness ( $b \bar{o} h \hat{u}$ ) is filled. In other words, the first three days give the backdrop for the creation drama while the last three days give the actual actors in the creation drama. Lee Haines throws further light on the creation account,

As the discourse analysis of this section indicates, the author in v. 2 focuses not on the "heavens" but on the "earth" where the reader/audience stands and presents the "earth" as "still" not being the earth which they all are familiar with. The earth which they are familiar with is "the earth" with vegetation, animals and man. Therefore, in a few verses, the author will mention their coming into existence through God's creation: vegetation on the third day and animals and man on the sixth day. Both the third and the sixth day are set as climaxes in the framework of this creation story and grand climax is the creation of man on the sixth day. ... The story of creation in Gen 1:1-2:3 thus tells us that it is God who created mankind "in his image" and provided for him an inhabitable and productive earth. ${ }^{58}$

Tsumura writes, "In conclusion, both the biblical context and extra-biblical parallels suggest that the phrase tōh $\hat{u}$ wā $\underline{b} \bar{o} h \hat{u}$ in Gen 1:2 has nothing to do with 'chaos' and simply means 'emptiness' and refers to the earth which is an empty place, i.e. 'an unproductive and uninhabited place." "59 This understanding of verse 2 fits well with the overall thrust and structure of Genesis 1:1-2:3.

\section{Choshek}

A closer analysis of this claim reveals that gap theorists take this position to avoid the idea that the earth left God's hands as formless void with darkness over its surface. ${ }^{60}$ Contrary to the argument that the word darkness symbolizes judgement, we find that God did not declare darkness as bad though He judged light as good (Gen 1:4, 18). He simply called this darkness "night", which was divided from "day" in the light. Darkness in Genesis 1 was the natural state of the earth undergoing construction by God. It was made for creation's good just as light was (Psalm 104:19-24). Morris helps us with the following quote,

There is, in fact, not a word in Scripture to connect Satan with the earth prior to his rebellion. On the other hand, when he sinned, he was expelled from heaven to the earth.... There is, therefore, no scriptural reason to connect Satan's fall in heaven with a cataclysm on earth.... That Satan was not on earth, at least not as a wicked rebel against God, prior to Adam's creation, is quite definite from Genesis 1:31. "And God saw everything that He had made, and...it was very good.” ...Therefore, Satan's sin must have occurred after man's creation ${ }^{61}$

\section{Theological Considerations}

The gap theory is not only invalid linguistically but also destructive theologically, at least, for the following reasons. First of all, the strange idea of a mysterious race of human before Adam contradicts Paul's reference to Adam as "the first man" (see 1 Cor 15:45). Secondly, the gap theorists' claim that sin and death existed before the Fall of humanity (in Gen. 3) cannot be supported by the biblical revelation about sin and death. ${ }^{62}$ The Bible declares unequivocally that death entered the world only when Adam brought sin into the world (Rom 5:12; 8:20-22; 1 Cor 15:21). Jesus' assertion that Abel's lifespan was at the "beginning of the world" (Luke 11: 50-51) also kicks against the gap theory.

More so, the Bible affirms that Adam and Eve were created on Day 6 of the Creation Week from the beginning of the creation of the heavens and the earth in Genesis 1:1 (cf. Mark 10:6). The insertion of the assumed long age of the earth between Genesis 1:1 and 1:2 contradicts the meaning of Mark 10:6 where Jesus affirms that the creations of Adam and Eve was at the beginning of the world. In Genesis 1:31, when God finished his work of creation, we read, "And God saw everything that he had made, and behold, it was very good." If the gap theory is true then God would be looking at an earth full of the results of rebellion, conflict, and terrible divine judgment and yet declared it as good. To think of death and suffering as existing billions of years before the sin of Adam is both theological unsound and blasphemous because such an idea lives God Himself as responsible for such a state. This paper takes the position that Satan's rebellion against God took place after God declared everything he created as good (in Gen. 1:31). To be more precise, Satan's fall and expulsion to the earth occurred sometime between Genesis 1:31 and the time that he appeared to Eve, in the body of a serpent (Gen. 3:1).

\section{CONCLUSION}

From the study, the key aspects of the gap theory can be summarized as follows: (1) God created a perfect earth and perfect heaven (Genesis 1:1); (2) Satan sinned against God; (3) God judged Satan and the world with a global flood

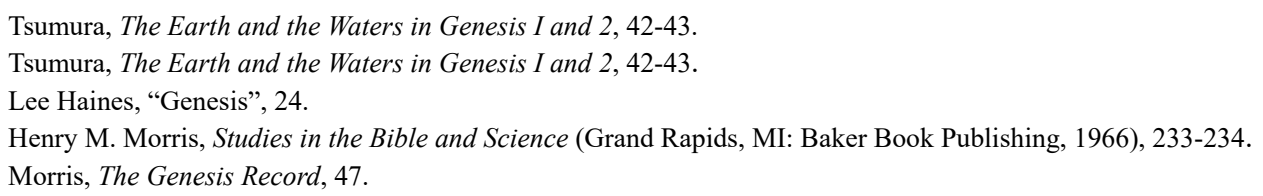


which formed the fossils of long geologic age (inferred from Jeremiah 4:23-26) the earth then became formless and void (Genesis 1:2); (4) a gap of eons of time is most commonly placed between Genesis 1:1 and 1:2, when God first created life, including "pre-adamite" pre-humans that flourished but became evil after Satan's fall; (5) The six-day creation was a re-creation of the world (Genesis 1:3-31).

Theologically, we have established that everything began with God, the One who acts and Who is the reason for which creation exist. The study found that the gap theory does not rest on solid exegetical, theological and linguistic grounds. I agree with Watchman Nee that "If both Genesis and geology are before us, what we follow must be Genesis and not geology because God is behind Genesis. If Genesis and geology differ, the error must be on the side of geology, for the authority of the Bible is beyond questioning." ${ }^{63}$ The gap theory will not work, either linguistically or theologically, and should be abandoned by those still using it. Genesis 1:2 is a positive description, not a negative one; therefore, though the earth was not yet ready for human habitation, there is no compelling reason to consider it as one which had experienced God's judgement. God wouldn't have described a world that was full of sin as "very good" (Gen 1:31). Genesis 1:2 must be taken as describing the condition of the earth as it was first created until God started to work on it to make it as it is presently.

\section{BIBLIOGRAPHY}

Agyekum, Kofi. Linguistics: Ethnography of Speaking. University of Ghana, Accra: Institute of Continuing and Distance Education, 2010.

Bandstra, Barry. Genesis 1-11: Baylor Handbook on the Hebrew Bible edited by W. Dennis Tucker Jr. Texas:

Baylor University Press, 2008.

Boaheng, Isaac. Basic Biblical Hebrew. Sunyani: Jonnette Secretarait, 2020.

Chryssides, George D. Christianity Today: An Introduction. London: A\&C Black, 2010.

Copan, Paul and William Lane Craig, Creation Out of Nothing: A Biblical, Philosophical, and Scientific Exploration. Leicester: Inter-Varsity Press, 2004.

Custance, Arthur C. Without form and Void: A Study of the Meaning of Genesis 1:2. Brookville, Canada: Doorway Papers, 1970.

Dake, Finis Jennings. Dake's Annotated Reference Bible. Georgia: Dake’s Publishing Inc., 2011.

Fields, W.W. Unformed and Unfilled. Collinsville, IL: Burgeners Enterprises, 1976.

Hamilton, Victor P. Handbook on the Pentateuch: Genesis, Exodus, Leviticus, Numbers, Deuteronomy. Grand Rapids, MI: Baker Book House, 1982.

Keathley, Kenneth and Mark F. Rooker. 40 Questions About Creation and Evolution. Grand Rapids, MI: Kregel Academic, 2014.

Kretzschmar, William A. Jr. The Emergence and Development of English: An Introduction. Cambridge: Cambridge University Press, 2018.

Leupold, H. C. Exposition on Genesis. Grand Rapids, MI: Baker Book House, 1942.

McIver, Tom. "Formless and Void: Gap Theory Creationism" in Creation/Evolution Journal Vol. 8. No. 3 (2008).

Miles Gentry, Spontaneous Combustion: Enlightenment and the Cosmic Crucible. np: Lulu.com, 2012.

Missler, Chuck. Supplemental Notes: The Book of Ezekiel. Coeur d'Alene: Koinonia House, 2008.

Morris, Henry M. Studies in the Bible and Science. Grand Rapids, MI: Baker Book Publishing, 1966.

The Genesis Record: A Scientific and Devotional Commentary on the book of Beginnings. Grand Rapids, MI: Baker Book House, 1998.

Nee, Watchman. The Mystery of Creation. New York: Christian Fellowship Publishers, Inc., 1981.

Ogilvie, Lloyd J. (ed), The Preacher's Commentary. Nashville, TN: Thomas Nelson, Inc., 1987.

Pember, G. H. Earth's Earliest Ages and Their Connection with Modern Spiritualism and Theosophy. London and Glasgow: Pickering \& Inglis, n.d.

Renn, Stephen D. (ed.). Expository Dictionary of Bible Words. Peabody, Massachusetts: Hendricks Publishers Marketing, Inc., 2005.

Reyburn, William D. and Euan McG Fry, A Handbook on Genesis. New York: United Bible Society, 1997.

Rimmer, Harry. Modern Science and the Genesis Record. Grand Rapids: Eerdmans, 1941.

Ryrie, Charles C. Systematic Theology. Chicago, IL: Moody Publishers, 1999), 210.

Simpson, Cuthbert A. "Genesis" in George Arthur Buttrick (ed.), The Interpreter's Bible Vol. 1. New York: Abingdon Press, 1956. 
Swaggart, Jimmy. Expositor's Study Bible. Baton Rouge: Jimmy Swaggart Ministries, 2013.

Tsumura, David T. "The Earth and the Waters in Genesis 1 and 2: A Linguistic Investigation," JSOT Supplement Series 83. Sheffield: JSOT Press, 1989.

Unger, Merrill. "Rethinking the Genesis Account of Creation" Bibliotheca Sacra 115:457 (1958).

Westermann, Claus. Genesis translated by David E. Green. London: T8.T Clark International, 2004. 